\title{
The Meaning and Symbols of the Batak Karo Ethnic Ritual Ceremony: Study of Semiotics
}

\author{
Jekmen Sinulingga ${ }^{1}$, Flansius Tampubolon ${ }^{2}$ \\ ${ }^{1,2}$ Faculty of Cultural Science, Universitas Sumatera Utara, Medan, Indonesia \\ jekmen@usu.ac.id
}

\section{Abstract}

This study aims to describe the meaning and symbol of the Cawir metua ritual ceremony, namely the death ceremony for the Karo community in Seberaya village, Karo district, North Sumatra Province. The method used in this research is a qualitative descriptive method which is done by collecting data by observation and interviews; descriptions that are bold and deep in nature, working with key informants. The theoretical framework used is the Social Semiotics approach, which is to interpret language in the sociocultural context in which culture is interpreted in semiotic terms as an information system. Based on the research that has been done, the authors obtained the results of the research, namely the symbolic meaning of the Cawir metua ceremony is the existence of symbols that have philosophical meanings in the Cawir metua ceremony.are still poor and need to be improved.
Keywords:

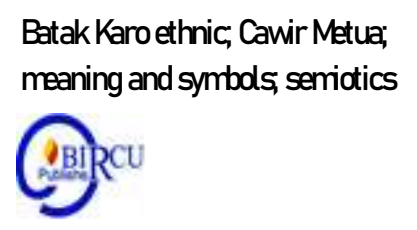

\section{Introduction}

Culture is the result of human thought that is passed down from generation to generation and is accepted by the heirs in their daily life. Customs are also rules or norms that serve as guidelines for life for every individual in life in the community and each individual is bound by predetermined norms or rules. In culture, one of the most important is the religious element, which is related to belief in God, God, and Spirit, which is believed to give peace and strength. In the implementation of the religious system, there are various forms of ceremony. One form of the ceremony is the transition ceremony. The transition ceremony is a ceremony that is carried out in relation to the stages of life. Culture is the result of human thought that is passed down from one generation to the next and is accepted by the heirs in their daily life. Customs are also rules or norms that serve as guidelines for life for every individual in life in the community and each individual is bound by predetermined norms or rules.

Ethnicity as one that sustains a sense of primordialism is often interpreted as a social group in a social or cultural system that has a certain meaning or position because of heredity, customs, religion, language, and so on. Members of an ethnic group have a common history (ancestry), language, value system, customs, and traditions. Overall, the ethnic group takes an important position in the social interaction of the intermingling process in all ethnic groups of indigenous peoples in the social community. (Angkat, 2019)

The traditional death ceremony is a ceremony that is carried out as a sign of final respect for the person who has passed away so that the family left behind always gets blessings in everyday life. The traditional death ceremony for the Karo tribe in Seberaya Village is one of the various cultures that exist in the Karo community in Karo Regency who really pay attention to manners and language methods in its implementation (Pinem, Kamarlin. 2013: 3). 
With its existence like that, Cawir Metua is a ceremony for someone who dies who is old and all of his children, whether male or female, are married. Thus it can be concluded that the most important requirement for someone who dies Cawir Metua is two, namely all children of the deceased are married, and both are elderly. Because the type of death that the author studied was Cawir Metua, the writer will first explain about the Cawir Metua. Usually the type of death belonging to the Cawir Metua group is people who die in an elderly condition where their children are married and already have grandchildren and granddaughters. When sick, this is usually the opportunity for the children to show their affection for the parent. They feed the parents and after eating, usually the parents give advice, teachings and blessings to the children. Sometimes, on this occasion the parents gave up their assets and assets. When someone dies in a cawir condition, all the relatives of the kalimbubunya (the parents-in-law of their sons' wives) must provide ose, which is to provide complete traditional clothing to be worn by brothers and sons and their wives as well as widow of the deceased (if the deceased is a man). This outfit is a sign of honor from the kalimbubunya party to the deceased (deceased). This type of death Cawir Metua cries the relatives showing grief as a farewell.

In Karo society, passing away at an old age and all of their children have been married is valued as a separate achievement called Cawir metua. The criteria for this Cawir metua are when all of their biological children are married and have fulfilled all their customary obligations. If someone dies in a cawir condition, then all relatives of the kalimbubu party must provide a complete ose er emas (complete traditional clothing) consisting of Sertali (jewelry made of gold gilding), headdresses, and hoods (customary uniul male cloth male and female). All of this will be used at the time of the ceremony by the deceased's brothers (husband and wife), sons of the deceased (husband and wife), and widows of the deceased (if the deceased is a man) (Ginting, SK 2014: 25). In the stages of the implementation of the Cawir metua ceremony, there are symbols that need to be known and passed on knowledge to future generations of the Karo community. Through this phenomenon, the researcher wants to examine the "meanings and symbols of the Batak Karo ethnic cawirmetua (death) ritual ceremony.

\section{Review of Literature}

\subsection{Defenition of Semiotics}

Semiotics is a scientific study of studying signs. In the study of semiotics considers that social phenomena in society and culture are signs, semiotics studies the systems, rules, and conventions that enable these signs to have meaning. Semiotic study is in two paradigms, namely the constructive paradigm. And the critical paradigm (Hashim, Ali Imran. 2014: 5).In short, Sobur (2003:15) states that semiotics is a science or analytical method for studying signs. The signs here are the tools we use in trying to find a way in this world, among humans and together with humans. Semiotics, or in Barhtes' terms, semiology, basically wants to study how humanity uses things.

Semiotics comes from the Greek word: semeion, which means sign. Meanwhile, semiotics /semiology is the study of signs and how they work (Fiske, 2004). Two pioneers of the semiotic method, namely Ferdinand de Saussure (1857-1913) and Charles Sander Peirce (1839-1914). According to Saussure, semiology is based on the assumption that human actions and behavior will carry a meaning, and the meaning of a sign is not an innate meaning but is generated through the sign system used in certain groups of people (Sunardi, 2004). 
Meanwhile, Peirce argues that human reasoning is always done through signs, meaning that humans are only able to reason through signs (Sunardi, 2004).

Tinarbuko (2008) states that semiotics is the study of signs, being able to know how these signs function and produce meaning. Signs are not limited to objects but are also gestures or human gestures. As a method of study, semiotics has shown its strength in various fields such as anthropology, sociology, politics, media studies, cultural studies. Meanwhile, semiotic imaging method has an influence on the fields of fine arts, film art, architecture, including visual communication design, and marketing. (Piliang in Tinarbuko, 2008). As "the science of signs" semiotics has specific and standard principles, systems, rules and scientific procedures. However, the understanding of science in semiotics cannot be equated with natural science which demands definite mathematical measures to produce an objective knowledge as a single truth. Semiotics is not a science that has the nature of certainty, unification and objectivity, but is built by "knowledge" which is more open to various interpretations. It is known that the logic of interpretation is not mathematical logic, which only recognizes the right or wrong category.

Social semiotics, namely semiotics which specifically examines the system of signs produced by humans in the form of symbols, both symbols in the form of words and symbols in the form of words in units called sentences. Halliday's book (1978) itself is entitled Language Social Semiotic. In other words, social semiotics examines the sign system contained in language. Social semiotics is the relationship of every human being to the human environment which has meaning, and this meaning will be interpreted by people who interact with each other by involving the environment.

\subsection{Definition of Meaning}

In human life there are many meanings and unconsciously, sometimes people use these meanings. All cultural meanings are created using symbols that point to events or objects (Spradley in Tinarbuko, 2008). Symbols involve three kinds of sign relationships. First, the sign's relationship with himself or what is called a symbolic relationship or internal relationship. Second, the relationship of signs with other signs in a system is called paradigmatic relations. Third, the relationship of signs with other signs of one structure is called syntagmatic relations or external relations. To develop a semiotic approach to modern culture, connotation theory is needed. In connotation theory, there are concepts about myth, metaphor, and rhetoric. But the connotation system uses denotation to talk about something else (Barthes in Tinarbuko, 2008). The denotative meaning includes the things indicated by words, or the explicit relationship between the sign and the reference or reality in the denotative stage of marking. For example, there are pictures of humans, animals, trees, houses in red, yellow, blue, and white. At the denotative stage only data information is submitted (Piliang in Tinarbuko, 2008). Whereas the connotative meaning includes aspects of color related to feelings and emotions as well as cultural values and the point of view of a community group, for example: a smiling face can be interpreted as an expression of happiness or an expression of humiliation, to understand the connotative meaning, other elements must be understood also (Piliang in Tinarbuko, 2008).

\section{Research Methods}

The research method used in this research is qualitative research using a descriptive approach where the researcher describes or describes the symbolic meaning of the Cawir metua ceremony in the Karo tribe in the Seberaya Village, Karo. Data will be obtained from interviews with residents and traditional leaders and will find out how the process of carrying 
out the Cawir metua ceremony and what symbols are contained in the implementation of the Cawir metua ceremony.

This research will be conducted in Seberaya Village, Tigapanah District, which is one of the villages located in Karo Regency, North Sumatra. The location selection for this research was due to the fact that the people of Seberaya village in carrying out their cultural activities still adhere to the elements contained in these cultural activities. Informants are insiders at the location where the research was held, or can also be people who are members of the community. Informants are people who are used to provide information about the situation and conditions of the research location (Kaelan, 2012: 89). In this study, researchers will conduct interviews with people who will be sources of information related to the Cawir metua ceremony and the meaning of the symbols contained therein.

\section{Discussion}

\subsection{Description of the Cawir metua ceremony}

In Karo culture, death ceremonies are generally referred to as nurun work or simatemate work. Then apart from that, there are three types of death in the customary concept of the Karo people, which are usually based on social status while they are still alive, namely: (a) Cawir metuah, (b) tabah-tabah galuh, and (c) mate nguda. What is meant by the Cawir metua ceremony is if the person who dies is old and already has children and grandchildren of all of his children. There is no certainty at what age a person who died can be categorized as Cawir metua.

In contrast to other types of death, many Cawir metua deaths are not mourned for, because basically the relatives do not show sadness, on the contrary they rejoice. The reason behind this attitude is that they are satisfied to give love and unfortunately as long as those who have passed away are still alive. A death like this is considered noble and highly valued. The funeral ceremony is called the accompanied by music and dance and the relatives and those present also dance together. With its existence like that, Cawir metua is a ceremony for someone who dies who has an advanced age and all of his children, whether male or female, are married. Thus it can be concluded that the most important conditions for someone who dies Cawir metua are two,

In the context of karo culture, the aim of conducting the Cawir metua traditional ceremony is as an icon of honor from the kalimbubu who died to the deceased. In this event, customary debts are submitted. This is an obligation that must be given to the kalimbubu. This type of naming custom money is different for each type of ceremony. In the Cawir metua ceremony, the traditional debt which is an obligation that must be given to the sukut is maneh-maneh. Consisting of bulang (uis gatip, traditional cloth), sekin (machete), and assistance (some money whose amount is determined based on the results of deliberation or bronze, and the amount of this money can be increased according to the request of the kalimbubu.

\subsection{Meaning and symbols in the Cawir metua ceremony}

The meanings and symbols contained in the Cawir metua traditional ceremony in the Karo community are as follows:

\section{a. Uis Adat (Traditional Clothing)}

At the Cawir metua traditional ceremony, almost all families and kade-kade 'guests' who attend must use the traditional uis. The custom uis used varies depending on who will use it. The meaning of all these fabrics is as the last tribute to the deceased and usually the uis 
used is the best cloth among all traditional fabrics. In addition, the cloth also means that the family left behind is sorry and sad for the death of the deceased.

\section{b. Amak mbentar}

Amak mbentar is a white mat made of woven pandanus. Amak mbentar has several sizes depending on its use. If it is used by 1-3 people the small and medium size is used, but if it is used by more than three people, the large one is used. This amak mbentar is an opening sign in every traditional ceremony, because before the traditional event begins, an erkimbang 'spreads out a mat' is carried out before the traditional event begins. In the traditional ceremony of Cawir metua in the Karo community, amak mbentar means the removal of disease. The point is that the death of the deceased will bring along all the diseases in the family so that the family left behind will be clean from all diseases.

\section{c. Terdas}

Terdas are grains of rice that are pounded with traditional tools so that the rice is separated between the skin and the rice. In the traditional ceremony of Cawir metua in the Karo community, the Terdas are usually put in large chopsticks and are upheld by the kalimbubu. At the Cawir metua traditional ceremony, there is a sign of separation. That is, just as rice that has been pounded will separate the skin from the rice and will not be able to reunite.

The meaning of terdas is death, which is likened to rice that is separated between the skin and the skin. Likewise, humans can never be together again between the living and the dead. So the family that is left behind does not have to regret the departure of the deceased and do not be sad for it to drag on.

\section{d. Kampil}

Kampil is a rectangular object that is generally used by women for betel nut and accessories such as whiting, gambier, tobacco, and areca nut. In everyday life, kampil is used for eating betel. Generally kampil is made of pandanus, some are decorated and some are not. The meaning of kampil is to respect and express love and to build bonds of brotherhood. In traditional ceremonies, if you do not give kampil first, it is considered disrespectful to all the guests who come. In traditional ceremonies the kampil is usually used as a decorated kampil. As with other traditional ceremonies, the cawir metua traditional ceremony, Kampil is a sign of the percentage of "asking permission", this can be seen at the bronze ceremony. In addition, kampil is delivered by the mothers of the sukut "who have an event" to kalimbubu, senina and new children.

e. Sen

The sign of pennies for 'money' is that what was given by the kalimbubu has been returned and is not borne by the deceased or other family members. This money is usually tied to the cloth that is used when dancing. The meaning of money at the time of payment of customary debt is to state that by giving the money, his duties and responsibilities in each custom event have been completed because he has died.

\section{f. Maneh-maneh}

Maneh-maneh is usually cloth or clothes that the deceased had used. These manehs can also be in the form of traditional fabrics, namely uis gara, uis nipes, beka buluh, dan kampuh. Maneh-maneh is a sign to declare that the dead are Cawir metua. The meaning of manehmaneh is tambar teran 'medicine for longing'. 


\section{Conclusion}

The death ceremony of Cawir metua is a ceremony carried out in the karo tribe where in its implementation there is no longer deep sadness among family members, but they dance as a form of respect because the parent has reached the highest expectation in his life, namely Cawir metua, a person who dies in an elderly condition where their children are married and already have grandchildren and granddaughters. Cawir metua death ceremony there are symbols and meanings inherent in the ceremony as a cultural symbol for the karo community.

\section{References}

Angkat, M. et al. (2019). Construction of Religious Identity in Pakpak Culture Community in Dairi District. Budapest International Research and Critics Institute-Journal (BIRCIJournal. P. 487-494

Alex Sobur. 2004. Semiotika Komunikasi. Bandung: Remaja Rosdakarya. Eriyanto. (2001). Analisis Wacana, pengantar analisis Teks Media. Yogyakarta: LKIS

Ginting, S.K. (2014). Ranan Adat. Medan: Penerbit Yayasan Merga Silima

Halliday, M.A.K. \& Hasan, R. 1992. Bahasa, Konteks, dan Teks: Aspek-Aspek Bahasa dalam Pandangan Semiotik Sosial: Gajah Mada University Press.

Hasyim, Ali Imran. (2014). Semiotika sosial Sebagai Alat Analisis teks dalam Penelitian Komunikasi Kualitatif. Jurnal Insani Vol 1.

Pinem, Kamarlin.(2013).Upacara adat cawirmetua pada etnis karo.jurnal Jupis vol 3.

Putra, B. (1995). Sejarah Karo Dari Zaman Ke Zaman. Medan : Ulih Saber

Saussure, Ferdinand. (1988). Pengantar Linguistik Umum. Yogyakarta : Universitas Gajah Mada Press.

Simon sabon ola.(2012).Makna dan nilai tuturan ritual lewak Tabo.jurnal Humaniora.Diakses tanggal 1 februari 2020.

Spradley, J., (1980). Participant Observation. New York: Holt, Rinehart and Winston.

Sumbo Tinarbuko. 2008. Semiotika Komunikasi Visual. Yogyakarta: Jalasutra 